\title{
Risk factors leading to peptic ulcer disease: systematic review in literature
}

\author{
Aghareed M. Asali ${ }^{1}$, Mohammed A. Alghamdi' ${ }^{2}$ Sumayah A. Fallatah ${ }^{2}$, Walaa A. Alholaily ${ }^{3}$, \\ Raja G. Aldandan ${ }^{3}$, Alaa H. Alnosair ${ }^{4}$, Ali A. AlKhars ${ }^{4}$, Moroj F. Alreheli ${ }^{2}$, \\ Mohammad O. Almohaini ${ }^{5}$, Rawabi A. Alharbi ${ }^{2}$
}

\author{
${ }^{1}$ Ibn Sina National College, Medical College of Ibn Sina National College, Jeddah, Saudi Arabia \\ ${ }^{2}$ Umm AlQura University, Medical College of Umm Al Qura University, Makkah, Saudi Arabia \\ ${ }^{3}$ Royal College of Surgeons, Dublin, Ireland \\ ${ }^{4}$ Imam Abdurahman Bin Faisal University, Medical College of Imam Abdulrahman Bin Faisal University, Dammam, \\ Saudi Arabia \\ ${ }^{5}$ University of Almaarefa, Medical College of Almaarefa colleges, Riyadh, Saudi Arabia
}

Received: 31 August 2018

Revised: 11 September 2018

Accepted: 12 September 2018

\section{*Correspondence:}

Dr. Aghareed M. Asali,

E-mail: aghareedasali@hotmail.com

Copyright: ( $)$ the author(s), publisher and licensee Medip Academy. This is an open-access article distributed under the terms of the Creative Commons Attribution Non-Commercial License, which permits unrestricted non-commercial use, distribution, and reproduction in any medium, provided the original work is properly cited.

\section{ABSTRACT}

This review is aiming to discuss the risk factors which lead to the occurrence of PUD during the period from July 2018 to August 2018. The present review was conducted by searching in Medline, Embase, Web of Science, Science Direct, BMJ journal and Google Scholar for, researches, review articles and reports, published over the past years. Books published on peptic ulcers and on the pathogenesis of human disease were also included., were searched up to August 2018 for published and unpublished studies and without language restrictions, the selected studies were summarized and un reproducible studies were excluded. If several studies had similar findings, we randomly selected one or two to avoid repetitive results. On the basis of findings and results this review found the H. Pylori and the use of NSAIDs are the most common risk factors for developing PUD, and also the genetic, stress and comorbidity increase the risk of PUD occurrence so successful eradication and prevention of the risk factors should be conducted to prevent the presence of PUD and is complication.

Keywords: Peptic ulcer disease, Risk factors, Helicobacter pylori, Non-steroidal anti-inflammatory drugs

\section{INTRODUCTION}

Peptic ulcer disease (PUD) is a common disease worldwide also known as peptic ulcer or stomach ulcers, PUD occurs as a defect in the mucosa of the stomach or duodenum that exceeds the muscularis mucosa. ${ }^{1,2}$ PUD follows gastric mucosal injuries as a result of imbalance between the defensive and the aggressive factors affecting the mucos. ${ }^{3,4}$ Many factors contribute to the development of PUD, of which environmental factors such as psychosocial conditions and stress are the most outstanding. ${ }^{5}$ Stress is an acute hazard/risk to homeostasis that excites an allostatic or adaptive response. Stress affects the function of the gastrointestinal tract either in short or long-term impacts. ${ }^{5}$ Studies revealed that stress contributes to the formation of PUD and is frequently used to produce PUD in experimental animal models. ${ }^{6}$ The life time for developing a peptic ulcer is approximately $10 \%{ }^{7}$ They resulted in 301,000 deaths in 2013 down from $327,000 .^{8}$ In western countries the percentage of people with Helicobacter pylori infections roughly matches age (i.e., $20 \%$ at age 20, 30\% at age 
$30,80 \%$ at age 80).prevalence is higher in developing countries where it is estimated at about $70 \%$ of the population, whereas developed countries show a maximum of $40 \%$ ratio. $^{9}$ In developing countries, where most children become infected by the age 10 of gastric cancer rates are very high. ${ }^{10}$ Researchers in Sabah, Malaysia confirmed a prevalence of $32.26 \%$ Helicobacter pylori infection in 1156 subjects, in age groups 12 to 80 years. ${ }^{11}$ In the past duodenal ulcer was 10 times as common in men as in women and gastric ulcer had a male preponderance of $3: 2$, now the frequency is much less, largely because of $H$. pylori eradication incidence being more even. ${ }^{12}$ The sale of antacid drugs worldwide exceeds $\$ 5$ billion, making ulcer disease major burden to the public healthcare system. ${ }^{6}$ In the UK as example mean initial in-hospital costs were $£ 2458(\mathrm{SE}=£ 216)$ per patient. Annual initial in-hospital costs of for all acute upper gastrointestinal bleeding (AUGIB) cases in the UK was estimated to be $£ 155.5$ million. ${ }^{13}$ Etiology of PUD include $H$. pylori infection, NSAIDS, pepsin, smoking, alcohol, bile-acids, steroids, stress, and changes in gastric mucin consistency (may be genetically determined). ${ }^{14,15}$ Other causes include Behcet disease, Zollinger Ellison syndrome, Crohn disease and liver cirrhosis, and similar symptoms stomach cancer, coronary heart disease, and inflammation of the stomach lining or gallbladder. ${ }^{16}$ Symptoms of PUD are nonspecific and diagnosis unreliable on history, frequent symptoms include, epigastric pain, nausea, flatulence and bloating, heartburn, a posterior ulcer may cause pain radiating to the back, and symptoms are relieved by antacid. ${ }^{17}$ Diagnosis is mainly established based on the characteristic symptoms, endoscopies or barium contrast and tests for $H$. pylori infection. ${ }^{18}$ Prognosis of PUD is excellent if the underlying cause such as $H$. pylori infection or drugs can be addressed. ${ }^{19}$

Despite the use of eradication therapy for the $H$. pylori infection and proton-pump inhibitors (PPIs), and advanced endoscopic therapy possibilities available during recent decades, mortality associated with PUD has not decreased concurrently with the incidence. ${ }^{20}$ So we aim to enforce the prevention of the PUD through known the risk factors. This article reviews the current literature regarding the risk factors of PUD. ${ }^{20}$

\section{METHODS}

The present review was conducted July 2018 to August 2018 in accordance with the preferred reporting items for systematic reviews and meta-analyses (PRISMA) declaration standards for systematic reviews. We reviewed all the topics on peptic ulcers, such as genetics, etiology, epidemiology, psychology, anatomy, neurology, bacteriology, pathology, and clinical statistics. To achieve this goal, we searched Medline, Embase, Web of Science, Science Direct, and Google Scholar for, researches, review articles and reports, published over the past 15 years. Books published on peptic ulcers and on the pathogenesis of human disease were also included.
Our search was completed without language restrictions. Then we extracted data on study year, study design, and key outcome on peptic ulcers. The selected studies were summarized and unreproducible studies were excluded. Selected data is shown in the Table 1.

\section{Inclusion criteria}

Inclusion criteria were peptic ulcer disease; age 15 to 70 years; males and females' patients, healthy or asymptomatic.

\section{Exclusion criteria}

Exclusion criteria were other condition involving stomach or duodenal such as Gastroenteritis, Gastritis, Gastroparesis, and malignancies.

\section{Data extraction and analysis}

Information relating to each of the systematic review question elements was extracted from the studies and collated in qualitative tables. Direct analysis of the studies of PUD is made with extreme caution, as different sampling techniques can provide bias as overview of the assemblage.

\section{RESULTS}

Common risk factors- causes for PUD and gastritis include infection with H.pylori, and NSAIDs. Less common risk factors include alcohol, smoking, cocaine, severe illness, autoimmune problems, radiation therapy and Crohn disease among others. ${ }^{21}$

H. pylori major causative factor $60 \%$ of gastritis and up to $50-75 \%$ duodenal ulcers) is chronic inflammation due to H.pylori that colonizes the antralmucosa. ${ }^{22}$

The immune system is unable to clear the infection, despite the appearance of antibodies. Thus the bacterium can cause a chronic active gastritis (type B gastritis). Gastrin stimulates the production of gastric acid by parietal cells. In $H$. pylori colonization responses to increased gastrin, the increase in acid can contribute to the erosion of the mucosa and therefore ulcer formation. ${ }^{22}$

H. pylori is able to survive and multiply in gastric environment, which is hostile to the growth of other bacteria. $^{23}$

Numerous adaptations permit survival of $H$. pylori in the acidic milieu of the stomach. ${ }^{24}$ Although most organisms appear to be adherent to the mucosal epithelial cells and form adherence pedestal resembling those produced by enteropathogenic Escherichia coli, several important adhesions have been identified. ${ }^{25,26}$ Bacterial lipopolysaccharide usually has proinflammatory activities, but $H$. pylori lipopolysaccharide has remarkable little. ${ }^{27} H$. pylori polysaccharide may express 
the type 11 Lewisx, Lewisy) neither, or both of these antigens as well as type 1 antigens (Lea, Leb). ${ }^{28}$ This observation is significant because these antigens are present on gastric epithelial cells, and there is evidence that host Lewis phenotype selects for the particular Lewis expression of the H. pylori population. ${ }^{29}$

H. pylori is highly associated with gastric ulcer disease. The pathogenic role of $H$. pylori in chronic active gastritis and its association between $H$. pylori and duodenal ulcer in 95 to $99 \%$ of patients is well established. ${ }^{30}$ All H. pylori spp. causes some degree of persistent inflammation in the mammalian stomach. Gastritis is found in virtually all infected humans, although the majority has no symptoms; only one in 10 develop ulcer disease. Gastric adenocarcinoma is 3 to 12 times more likely to develop in individuals infected with H.pylori. ${ }^{31}$ There a number of postulated mechanisms whereby $H$. pylori can cause injury to mucosa, urease can result in ammonia production and hemostatic factors and cytotoxins (e.g., protease, lipases and phospholipase A and vacuolating cytotoxin) can cause injury. ${ }^{1} H$. pylori is more likely to associated with the early or initial states of primary gastric lymphoma than advanced tumors; $H$. pylori can disappear during progression of gastric lymphoma. $^{32} H$. pylori-specific IgG antibody concentrations can be expected to fall significantly after successful antibacterial therapy. ${ }^{33}$ A symptomatic and untreated patients continue to test $\operatorname{IgG}$ seropositive as long as $H$. pylori is present, even after histological resolution. ${ }^{34}$ Eradication of $H$. pylori is associated with significant reduction in duodenal ulcer recurrence and is also useful in differentiating between $H$. pylori gastritis and gastric MALT lymphoma (mucosa-associated lymphoid tissue). ${ }^{35,36}$ In $H$. pylori infected patients who develop gastric cancer, serum IgG against CagA is $94 \%$ sensitive and $93 \%$ specific; indicating that detection of antibodies to $\mathrm{CagA}$ is useful marker for diagnosis of duodenal and gastric cancer. ${ }^{37}$

\section{Non-steroidal anti-inflammatory drugs (NSAIDs)}

Worldwide studies have confirmed that $H$. pylori infection was present in more than $90 \%$ of patients with duodenal ulcers and about $85 \%$ of those with gastric ulcers, and they suggested that majority of the remaining ulcers were related to the use of NSAIDS. ${ }^{23,38}$ The use of NSAIDS is the major cause of peptic ulcers, although the pathophysiological interaction between $H$. pylori infection and NSAIDS is still controversial. ${ }^{39}$ Surprisingly, a number of recent reports from around the world, especially from the United States and Australia suggest a relatively low prevalence of infection of $H$. pylori in duodenal and gastric ulcers, even when the users of NSAIDS are excluded. ${ }^{40}$ In the greater Rochester area, New York, only $61 \%$ of patients with non-NSAIDS induced duodenal as well as gastric ulcer showed the presence of $H$. pylori, but the situation is not the same outside the USA. ${ }^{41}$ In Europe, three studies from Scotland, Denmark, and Italy show a prevalence of $H$. pylori-negative ulcer $10-15 \%$ which is lower than that observed in the US, but still higher than expected. ${ }^{42,43}$ NSAIDs interfere with mucosal defense in the stomach via direct toxic effects in addition to cyclooxygenase inhibition and depletion of endogenous prostaglandins. ${ }^{44}$ Among drugs diclofenac and aspirin are the most common commonly associated drugs. ${ }^{45}$ Aspirin increases the risk for gastric ulcer in patients of all ages, whereas non aspirin, non-steroidal use increases the gastric ulcers to varying degrees in patients over 55,depending on race and history of ulcer. ${ }^{46}$ The use of NSAIDs increases the risk of peptic ulcer 3 -anf 5 fold in $H$. pylori positive and H. pylori negative patients, respectively. ${ }^{47}$ The success of eradication therapy should always be confirmed, because of the risk of ulcer recurrence and bleeding in $H$. pylori infected patients who require anti-inflammatory treatments. $^{48}$

Past gastric ulcer and family history of ulcer disease is an increased risk of recurrence with $H$. pylori infection. ${ }^{49}$ Family history of gastric ulcer disease is a risk factor, as there is some genetic predisposing to develop the disease, but there is no genetic relationship in developing $\mathrm{H}$. pylori infection. ${ }^{50}$ Some research results suggest that there is a significant association between genetic polymorphism at the PGR-RFLP gene locus and gastric body ulcer. ${ }^{51}$ Genetic play an important role in ulcer pathogenesis. The concordance for peptic ulcer in identical twins is approximately $50 \%$, and the lifetime prevalence of developing ulcer in first degree relatives of ulcer patients is about three-fold greater than in the general population. The inheritance of blood group 0 is associated with modest (1.3 fold) increase in duodenal ulcer. $^{52}$

\section{Stress and diet}

Stress due to serious health problems such as those requiring treatment in an intensive care unit is well described as a cause of peptic ulcers, which are termed stress ulcers. ${ }^{53}$ While chronic life stress was once believed to be the main cause of ulcers this is no longer the case. It is, however, still occasionally believed to play a role. ${ }^{54}$ Dietary factors such as spice consumption, were hypothesized to cause ulcers until late in the 20th century, but have been shown to be of relatively minor importance. ${ }^{55}$ Caffeine and coffee, and also commonly thought to cause or exacerbate ulcers, appear to have little effect. ${ }^{56}$ Skipping of meals allows gastric acid to directly act on surface mucosa of the stomach causing irritation which ultimately leads to gastric ulcers. Gastric ulcers cause abdominal pain which aggravate with meals. ${ }^{57}$

\section{Smoking and alcohol}

Consumption of alcohol and smoking are risk factors. Chronic alcohol disturbs gastric mucosal barrier by inhibiting COX 1 receptor enzymes which reduce the production of cytoprotective prostaglandin. Cigarette smoking causes reduction of circulating epidermal 
growth factor and increase free radical production in gastric mucosa. ${ }^{58,59}$

Although some studies have found correlations between smoking and ulcer formation. Others have been more specific in exploring the risks involved and have found that smoking by itself may not be much of a risk factor unless associated with $H$. pylori infection. ${ }^{60,61}$ Researchers in Denmark in a series of 2416 subjects found that tobacco smoking and $H$. pylori infection are the main risk factors for PUD in Danish adults. ${ }^{62}$

Studies have found that alcohol consumption increases risk when associated with $H$. pylori infection, it does not seem to independently increase risk. Even coupled with $H$. pylori infection, the increase is modest in comparison to the primary risk factor. ${ }^{61}$ Satarasinghe and colleagues in a series of 1500 patients found alcohol was a contributory factor in one third of gastrointestinal bleeding (IGIB) patients. ${ }^{63}$

\section{Elderly patient}

Study show a 7-year follow-up, aging hemodialysis patients had significantly higher incidences of PUB than the matched controls. ${ }^{6}$

Table 1: Risk factors of peptic ulcers.

\begin{tabular}{|c|c|c|c|}
\hline Risk factor & Sample & Author and year & Key points \\
\hline Genetic $^{65}$ & $\begin{array}{l}3159 \text { cases and } 2816 \\
\text { controls }\end{array}$ & $\begin{array}{l}\text { Ma, Wu, Hu, Li, Cao, } \\
\text { Dong, } 2017\end{array}$ & $\begin{array}{l}\text { IL-1B-31C/T gene polymorphisms might } \\
\text { increase H. pylori infection risk. IL-1B- } \\
511-\mathrm{C} / \mathrm{T} \text { and IL-8-251T/A gene } \\
\text { polymorphisms might -related diseases } \\
\text { including GC or PUD }\end{array}$ \\
\hline Obesity $^{66}$ & 47,120 men & $\begin{array}{l}\text { Boylan, Khalili, Huang, } \\
\text { and Chan, } 2014\end{array}$ & $\begin{array}{l}\text { In a large prospective cohort of male } \\
\text { health professionals, central and total } \\
\text { obesity wereassociated with increased risk } \\
\text { of peptic ulcer-particularly gastric and } \mathrm{H} \\
\text { pylori-negative ulcers. }\end{array}$ \\
\hline Inflammatory $^{67}$ & 120 & $\begin{array}{l}\text { Tourani, Habibzadeh } \\
2018\end{array}$ & $\begin{array}{l}\text { Increased level of TNF- } \alpha \text { could probably } \\
\text { play pivotal role in pathogenesis of peptic } \\
\text { ulcer in the presence of } H \text {. pylori }\end{array}$ \\
\hline Psychosomatics $^{68}$ & 166 & $\begin{array}{l}\text { Levenstein, Jacobsen, } \\
\text { Rosenstock \& Jørgensen } \\
\text { (2017) }\end{array}$ & $\begin{array}{l}\text { A vulnerable personality raises risk for } \\
\text { hospital-diagnosed peptic ulcer, in part } \\
\text { because of an association with health risk } \\
\text { behaviors. }\end{array}$ \\
\hline H. pylori $^{74}$ & 2416 Danish & $\begin{array}{l}\text { Rosenstock, Jørgensen, } \\
\text { Bonnevie, Andersen, } \\
2003\end{array}$ & $\begin{array}{l}\text { Tobacco smoking and } \mathrm{H} \text { pylori infection } \\
\text { are the main risk factors for PUD in } \\
\text { Danish adults }\end{array}$ \\
\hline Hostility $^{69}$ & 13,539 & $\begin{array}{l}\text { By Lemogne, Cédric, } \\
\text { Schuster, } 2015\end{array}$ & $\begin{array}{l}\text { Hostility might be associated with an } \\
\text { increased risk of peptic ulcer. }\end{array}$ \\
\hline NSAIDs $^{70}$ & & $\begin{array}{l}\text { Tomizawa, Shinozaki, } \\
2017\end{array}$ & $\begin{array}{l}\text { Immunosuppressive agents were } \\
\text { correlated with peptic ulcer }\end{array}$ \\
\hline Hypoalbuminemia $^{71}$ & 18435 & $\begin{array}{l}\text { Hu, Huang and Chang, } \\
2016\end{array}$ & $\begin{array}{l}\text { Patients diagnosed with hypoalbuminemia } \\
\text { have a significantly elevated risk of } \\
\text { developing PUB }\end{array}$ \\
\hline Epstein-Barr virus ${ }^{72}$ & $\begin{array}{l}\text { Healthy individuals, } \\
\mathrm{n}=129, \\
\text { and PUD patients } \\
\text { ( } \mathrm{n}=78,58 \text { duodenal } \\
\text { and } 20 \text { gastric } \\
\text { ulcers). }\end{array}$ & $\begin{array}{l}\text { Cárdenas-Mondragón, } \\
\text { Torres, } 2015\end{array}$ & $\begin{array}{l}\text { Study suggests that EBV reactivation in } \\
\text { gastric and duodenal epithelium increases } \\
\text { the risk to develop PUD. }\end{array}$ \\
\hline Tobacco smoking ${ }^{73}$ & 2416 Danish & $\begin{array}{l}\text { Rosenstock, Jørgensen, } \\
\text { Bonnevie, Andersen, } \\
2003\end{array}$ & $\begin{array}{l}\text { Tobacco smoking and } \mathrm{H} \text { pylori infection } \\
\text { are the main risk factors for PUD in } \\
\text { Danish adults }\end{array}$ \\
\hline Healthcare workers ${ }^{74}$ & $\begin{array}{l}50,226 \text { physicians, } \\
122,357 \text { nurses, } \\
20,677 \text { pharmacists, } \\
\text { and } 25,059 \text { other } \\
\text { HCWs }\end{array}$ & $\begin{array}{l}\text { Lin, Weng, Lin, Hsu, } \\
\text { Wang, Su, et al. (2015) }\end{array}$ & $\begin{array}{l}\text { Nurses and other HCWs had a } \\
\text { significantly } \\
\text { higher PUD risk than did the general } \\
\text { population }\end{array}$ \\
\hline
\end{tabular}




\section{DISCUSSION}

The main purpose of this article was to determine the risk factors which lead to the occurrence of PUD, in which there are common risk factors - causes for PUD include infection with $H$. pylori, and NSAIDs. Less common risk factors include alcohol, smoking, cocaine, severe illness, autoimmune problems, radiation therapy and Crohn disease among others. ${ }^{21}$

H. pylori is considered to be major causative factor $60 \%$ of gastritis and up to $50-75 \%$ duodenal ulcers. ${ }^{22}$ The large sample of the Danish study indicate the huge contribution of the Helicobacter pylorus as the number one risk factor in PUD, And the use of NSAIDs and immunosuppressive agents were correlated with peptic ulcer. Genetic factor as people have IL-1B-31C/T gene polymorphisms might increase $\mathrm{H}$. pylori infection risk, and also IL-1B-511-C/T and IL-8-251T/A gene polymorphism might act as a risk factor to $\mathrm{H}$. pylori-related diseases including GC or PUD.

In a large prospective cohort of male health professionals, central and total obesity were associated with increased risk of peptic ulcer particularly gastric and $H$. pylorinegative ulcers, which may indicate the higher incidence in general population or it may be cofactor with the higher stress and work pressure which found in heath field. $^{66}$

There is also an inflammatory predisposing factor in which increased level of TNF- $\alpha$ could probably play pivotal role in pathogenesis of peptic ulcer in the presence of $H$. pylori.

On the other hand, the personality and the psychological aspect of the person have great association with the occurrence of the PUD through the life time as result of stress or the vulnerability of the person. Vulnerable personality raises risk for hospital-diagnosed peptic ulcer, in part because of an association with health risk behaviors. Its impact is seen in 'idiopathic' and $H$. pylori -associated ulcers, and in acute surgical cases. ${ }^{68}$ Hostile behavior is also might be associated with an increased risk of peptic ulcer. In a prospective study of a population-based Danish cohort, psychological stress increased the incidence of peptic ulcer, in part by influencing health risk behaviors. Stress had similar effects on ulcers associated with $H$. pylori infection and those unrelated to either $H$. pylori or use of non-steroidal anti-inflammatory drugs. ${ }^{75}$

Severely ill and people with chronic illness, whereas aging hemodialysis patients had significantly higher incidences of PUB than the matched controls. ${ }^{64}$ And also co morbidity in patients diagnosed with hypoalbuminemia has a significantly elevated risk of developing PUB.

EBV play a significant role as risk factor for PUU, in which Duodenal PUD was significantly associated with high anti-EBV IgG titers ( $\mathrm{p}=0.022$, OR=2.5), while antiEBV IgA was positively associated with gastric PUD $(\mathrm{p}=0.002, \mathrm{OR}=10.1)$, which indicate the EBV reactivation in gastric and duodenal epithelium increases the risk to develop PUD.

Health care workers (HCWs) in Taiwan have heavy, stressful workloads, are on-call, and have rotating nightshifts, all of which might contribute to peptic ulcer disease (PUD). Subgroup analysis for physician specialties was also done. Nurses and other HCWs had a significantly higher PUD risk than did the general population (odds ratio [OR]: 1.477; 95\% confidence interval [CI]: 1.433-1.521 and OR: 1.328; 95\% CI: 1.245-1.418, respectively); pharmacists had a lower risk (OR: 0.884; 95\% CI: 0.828-0.945); physicians had a nonsignificantly different risk (OR: 1.029 ; 95\% CI: $0.987-$ 1.072). In the physician specialty subgroup analysis, internal medicine, surgery, Ob/Gyn, and family medicine specialists had a higher PUD risk than other physicians (OR: 1.579 ; 95\% CI: 1.441 1.731, OR: $1.734 ; 95 \%$ CI: 1.565-1.922, OR: 1.336 ; 95\% CI: $1.151-1.550$, and OR: 1.615; 95\% CI: 1.425-1.831, respectively). In contrast, emergency physicians had a lower risk (OR: 0.544; $95 \%$ CI: $0.359-0.822) .^{74}$

\section{CONCLUSION}

H. pylori and the use of NSAIDs are the most common risk factors for developing PUD, and also the genetic, stress and comorbidity increase the risk of PUD occurrence, as also the work stress in the medical field play significant role as risk for developing PUD so successful eradication and prevention of the risk factors should be conducted to prevent the presence of PUD and is complication.

\section{Funding: No funding sources \\ Conflict of interest: None declared \\ Ethical approval: Not required}

\section{REFERENCES}

1. Leontiadis GI, Sreedharan A, Dorward S, Barton P, Delaney B, Howden CW, et al. Systematic effectiveness of proton pump inhibitors in acute upper gastrointestinal bleeding. Health Technol Assess. 2007;11(51):3-164.

2. Ramakrishnan K, Salinas RC. Peptic ulcer disease. Am Fam Physician. 2007;76(7):1005-12.

3. Rosenstock S, Jorgensen T, Bonnevie O, Andersen L. Risk factors for peptic ulcer disease: a population based prospective cohort study comprising 2416 Danish adults. Gut. 2003;52(2):186-93.

4. Lee YC, Cheng CW, Lee HJ, Chu HC. Apple polyphenol suppresses indomethacin-induced gastric damage in experimental animals by lowering oxidative stress status and modulating the MAPK signaling pathway. J Med Food. 2017;20(11):111320. 
5. Bhatia V, Tandon RK. Stress and the gastrointestinal tract. J Gastroenterol Hepatol. 2005;20(3):332-9.

6. Brzozowski T, Konturek PC, Chlopicki S, Sliwowski Z, Pawlik M, Ptak-Belowska A, et al. Therapeutic potential of 1-methylnicotinamide against acute gastric lesions induced by stress: role of endogenous prostacyclin and sensory nerves. J Pharmacol Exp Ther. 2008;326(1):105-16.

7. Snowden FM. Emering and Reemerging Diseases: Historical Perspective. Immunol Rev. 2008;225(1):9-26.

8. GBD 2013 Mortality and Causes of Death, Collaborators (17 December). Global, Regional, And National Age-Sex Specific All Cause and Cause Specific Mortality for 240 Causes of Death, 1990-2013: A Systematic Analysis for The Global Burden of Disease Study. Lancet. 2013.

9. Brown LM. Helicobacter Pylori: Epidemiology and Routes of Transmission. Epidemiol Rev. 2000;22(2):283-97.

10. Telford J, Covacci A, Ghiara MP, Montecucco C, \& Rappuoli R. Unraveling the pathogenic role of Helicobacter pylori in peptic ulcer: Potential new therapies and vaccines. Trends in Biotech. 1994;12(10):420-6.

11. Mustafa M, Jayaram Menon. Seroprevalenceand. Risk Factors for Helicobacter Pylori Infection in East Malaysian Community. Int J Med Pharm Sci. 2013;3(5):49-56.

12. Dyspepsia and Gastroioesophageal Reflux Disease: Investigation and Management of DyspepsiaSymptoms Suggestive of Gastroioesophegeal Reflux Disease-Or Both; NICE Clinical Guideline, 2014.

13. Campbell H, Stokes E, Bargo D, Logan R, Mora A, Hodge R, et al. Costs and quality of life associated with acute upper gastrointestinal bleeding in the UK: cohort analysis of patients in a cluster randomized trial. BMJ Open. 2015;5:e007230.

14. Mynatt RP, Davis GA, Romanelli F. Peptic Ulcer Disease: Clinically Relevant Causes and Treatment. Orthopedics. 2009;32(2):104.

15. Niv Y. H. pylori/NSAIDS-Negative Peptic UlcerThe Mucin Theory. Med Hypotheses. 2010;75(5):433-5.

16. Najm WI. Peptic Ulcer Disease. Primary Care. 2011;38(3):383-94.

17. Merck Manuals. Home health Handbook for Patients \& Caregivers: Peptic ulcer, 2006. Available https://www.merckmanuals.com/home/digestivedisorders/gastritis-and-peptic-ulcer-disease/pepticulcer-disease. Accessed 19 August 2018.

18. Prabu V, Shivani A. An Overview of History Pathogenesis and Treatment of Perforated Peptic Ulcer Disease with Evaluation of Prognostic Scoring in Adults. Ann Med Health Sci Res. 2014;4(1):22-9.

19. Van Der, Hulst R, Tytgat G. Helicobacter pylori and Peptic Ulcer Disease. Scandinavian Journal of Gastroenterology.1996;31(sup220):10-8.
20. Malmi H. Peptic ulcer: incidence, associated morbidity, and mortality (PhD). University of Helsinki, 2018.

21. Jones L, Brooks D. Cash. Gastritis, 2015. Available at https://www.niddk.nih.gov/health-information/ digestive-diseases/gastritis. Accessed 19 August 2018.

22. Human pathology. Antral mucosa, 2014. Available at http://www.humpath.com/spip.php?article7501. Accessed 19 August 2018.

23. Marshall BJ, Warren JR. Unidentified Curved Bacilli in the Stomach Patients with Gastritis and Peptic Ulceration. Lancet I. 1984;(8390):1311-5.

24. Amieva M. Disruption of the Epithelial ApicalJunctional Complex by Helicobacter pylori CagA. Science. 2003:300:1430-4.

25. Smoot DT, Resau JH, Naab T, Desbordes BC, Gilliam T, Bull-Henry $\mathrm{K}$, et al. Adherence of Helicobacter Pylori to Cultured Human Gastric Epithelial Cells. Infect Immun.1993;61:350-5.

26. Hemalatha S, Drumm B, Sherman P. Adherence of Helicobacter pylori to human gastric epithelial cells in vitro. J Medical Microbiol. 1991;35:197-202.

27. Ilver D. Helicobacter pylori Adhesion Binding Fucosylated Histo-Blood Group Antigens Revealed by Retagging. Science. 1998;279:373-7.

28. Perez-Perez GI, Shepherd VI. Morrow JD, Blaser MJ. Activation of Human THP-1 And Rat Bone Marrow -Derived Macrophages by Helicobacter Pylori Lipopolysaccharide. Infect Immun. 1995;63:1183-7.

29. Appelmelk B, Martino M, Veenhof E, Monteiro M, Maaskant J, Negrini R, et al. Phase Variation in $\mathrm{H}$ Type I and Lewis a Epitopes of Helicobacter pylori Lipopolysaccharide. Infection Immunity. 2000;68(10):5928-32.

30. Wirth H, Yang M, Peek R, Tham K, Blaser M. Helicobacter pylori Lewis expression is related to the host Lewis phenotype. Gastroenterology. 1997;113:1091-8.

31. National Institutes of Health Consensus Development Conference. Helicobacter Pylori in Peptic Ulcer Disease. JAMA. 1994;272:65-9.

32. Tompkins IS, Fallow S. The New Path to Preventing Ulcers. Science. 1995;267:1621-2.

33. Nakamura S, Yao T, Aoyagi K, Iida M, Fujishima M, Tsuneyoshi M. Helicobacter pylori and primary gastric lymphoma. Cancer.1997;79(1):3-11.

34. Hirschl A, Rathbone B, Wyatt J, Berger J, \& Rotter M. Comparison of ELISA antigen preparations alone or in combination for serodiagnosing Helicobacter pylori infections. J Clin Pathol. 1990;43(6):511-3.

35. Loffeld R, Stobberingh E, Van Spreeuwel J, Flendrig J, Arends J. The prevalence of antiHelicobacter (Campylobacter) pylori antibodies in patients and healthy blood donors. J Med Microbiol. 1990;32(2):105-9. 
36. Patchett S, Beattie S, Leen F. Helicobacter Pylori and Duodenal Ulcer Recurrence. Am J Gastroentrol. 1992;87:24-7.

37. Stolte M. Helicobacter Pylori Gastritis and Gastric MALT-Lymphoma [Letter]. Lancet. 1992;339:7456.

38. Torres J, Pérez-Pérez G, Leal-Herrera Y, \& Muñoz O. Infection with $\mathrm{Cag} \mathrm{A}+$ Helicobacter pylori strains as a possible predictor of risk in the development of gastric adenocarcinoma in Mexico. Int $\mathrm{J}$ Cancer. 1996;78:298-300.

39. Kuipers Ej, Thijs JC, Festen HP. The Prevalence of Helicobacter Pylori in Peptic Ulcer Disease. Phamacol Ther. 1995;9:59-69.

40. Chan FK, Leung WK. Peptic Ulcer Disease. Lancet. 2002;360:933-41.

41. Quan C, Talley NJ. Management of Peptic Ulcer Disease Not Related to Helicobacter Pylori or NSAIDS. J Gastroenterol. 2002;97:2850-61.

42. Jyotheeswaran S. Prevalence of Helicobacter pylori in Peptic Ulcer Patients in Greater Rochester, NY: Is Empirical Triple Therapy Justified? Am J Gastroenterol. 1998;93(4):574-8.

43. Meucci G, Battista R, Abbiati C, Benassi R, Bierti L, Bortoli A, et al. Prevalence and Risk Factors of Helicobacter pylori-negative Peptic Ulcer. J Clin Gastroenterol. 2000;31(1):42-7.

44. McColl K, El-Nujumi A, Chittajallu R, Dahill S, Dorrian C, el-Omar E, et al. A study of the pathogenesis of Helicobacter pylori negative chronic duodenal ulceration. Gut. 1993;34:762-8.

45. Scheiman JM. NSAIDs-Induced Peptic Ulcer Disease: A Critical Review of Pathogenesis and Management. Drug Dis. 1994;12:210-22.

46. Hawthorne A, Mahida Y, Cole A, Hawkey C. Aspirin-induced gastric mucosal damage: prevention by enteric-coating and relation to prostaglandin synthesis. $\mathrm{Br} \mathrm{J}$ Clin Pharmacol. 1991;32(1):77-83.

47. Schubert T, Bologna S, Nensey Y, Schubert A, Mascha E, MA C. Ulcer risk factors: Interactions between Helicobacter pylori infection, nonsteroidal use, and age. Am J Med. 1993;94(4):413-8.

48. Voutilainen M, Mäntynen T, Fär M. Impact of NonSteroidal Anti-inflammatory Drug and Aspirin Use on the Prevalence of Dyspepsia and Uncomplicated Peptic Ulcer Disease. Scandinavian Journal of Gastroenterology. 2001;36(8):817-21.

49. Hunt R, Bazzoli F. Should NSAID/low-dose aspirin takers be tested routinely for H. pylori infection and treated if positive? Implications for primary risk of ulcer and ulcer relapse after initial healing. Alimentary Pharmacol Therap. 2004;19(s1):9-16.

50. Kim J, Kim N, Lee B, Kang J, Seo P, Lim M, et al. Risk Factors for Development and Recurrence of Peptic Ulcer Disease. Korean J Gastroenterol. 2010;56:220.

51. Ohtaki Y, Azuma T, Konishi J, Ito S, \& Kuriyama M. Association between genetic polymorphism of the pepsinogen $\mathrm{C}$ gene and gastric body ulcer: the genetic predisposition is not associated with Helicobacter pylori infection. Gut. 1997;41(4):46974.

52. Rotter JI. Peptic Ulcer: In Emery AEH, Rimoin DL. Editors. The Principles and Practice of Medical Genetics. New York: Churchill Livingstone. 1983: 863.

53. Steinberg KP. Stress- Related Mucosal Disease in The Critically Ill Patient: Risk Factors and Strategies to Prevent Stress-Related Bleeding in The Intensive Care Unit. Critical Care Med. 2002;30:S362-4.

54. Fink G. Stress Controversies: Post-Traumatic Stress Disorder, Hippocampal Volume, Gastroduodenal Ulceration. J Neuroendocrinol. 2011;23(2):107-17.

55. National Digestive Diseases Information Clearinghouse. Available at http://digestive.niddk. nih.gov/dddiseases/pubs/hpy. Accessed 19 August 2018.

56. Rayan Harshman M, Aldoori W. How Diet and Lifestyle Affect Duodenal Ulcers. Review of The Evidence. CandFamily Physi Med Medecin De Famille Canadien. 2004;50:727-32.

57. Harju E. The Complaints and Dietary Habits of the Patients with Gastritis and Undefined Abdominal Pain. ChirItal. 1985;37(1):29-36.

58. Ko JK, Cho CH. Alcohol drinking and Cigarette Smoking A" Partner for Gastric Ulceration. Zhonghua Yi XueZa Zhi. 2000;63(12):845-54.

59. Mal Chow JY, Cho CH. Effects of Cigarette Smoking On Gastric Ulcer Formation and Healing Mechanisms of Action Clin Gastroenterol. 1998;80:6.

60. Kato I, Nomura A, Stemmermann G, Chyou P. A Prospective Study of Gastric and Duodenal Ulcer and Its Relation to Smoking, Alcohol, and Diet. Am J Epidemiol. 1992;135:521-30.

61. Salih, B. A. H pylori infection and other risk factors associated with peptic ulcers in Turkish patients: A retrospective study. World J Gastroenterol. 2007;13(23):3245.

62. Rosenstock, S. Risk factors for peptic ulcer disease: A population based prospective cohort study comprising 2416 Danish adults. Gut. 2003;52(2):186-93.

63. Satarasinghe R, Silva AD, Arulnithy K, Abeyratne P, Jayawardana M. Aetiology and other features of a cohort of adult Sri Lankans presenting with upper gastrointestinal bleeding (UGIB). Journal of the Ceylon College of Physicians. 2011;41(2):57.

64. Lin X-H, Lin Chung-Chi, Wang Yuan-Jen, Luo Jiing-Chyuan, Young Jiing-Chyuan, Chen PingHsien, et al. Risk factors of the peptic ulcer bleeding in aging uremia patients under regular hemodialysis, J Chinese Med Assoc. 2018;03:007.

65. Ma J, Wu D, Hu X, Li J, Cao M, Dong W. Associations between cytokine gene polymorphisms and susceptibility to Helicobacter pylori infection and Helicobacter pylori related gastric cancer, 
peptic ulcer disease: A met analysis. PLoS. 2017; 12:e0176463.

66. Boylan MR, Khalili H, Huang ES, Chan MT, Measures of Adiposity Are Associated with Increased Risk of Peptic Ulcer. Clin Gastroenterold Hepatol. 2014.

67. Tourani M, Habibzadehb M, Karkhahb A, ShokriShirvanic J, Ladan G, et al. Association of TNF- $\alpha$ but not IL-1 $\beta$ levels with the presence of Helicobacter pylori infection increased the risk of peptic ulcer development, Cytokine. 2018;110:2326.

68. Levenstein S, Jacobsen RK, Rosenstock S \& Jørgensen T. Mental vulnerability, Helicobacter pylori, and incidence of hospital-diagnosed peptic ulcer over 28 years in a population-based cohort, Scandinavian J Gastroenterol. 2017;52:9:954-61.

69. Lemogne C, Schuster JP, Levenstein S, Melchior M, Nabi H, Ducimetiere P, et al. Hostility and the risk of peptic ulcer in the GAZEL cohort. Health Psychol. 2015;34(2):181-5.

70. Tomizawa, Fuminobu S, Rumiko H, Yoshinori S, Yasufumi M, Takao S, et al. Immunosuppressive agents associated with peptic ulcer bleeding, experimental and therapeutic medicine. 2017;13:1927-31.

71. Hu HY, Huang N, Chang SS. Higher Risk of Developing Peptic Ulcer Bleeding in Adult Patients
Diagnosed with Hypoalbuminemia. Gen Med (Los Angeles). 2017;4:277.

72. María G. Cárdenas-Mondragón, Javier Torres, Lourdes Flores-Luna, Ricardo Carreón-Talavera, Margarita Camorlinga-Ponce, Ezequiel M. et al. Epstein-Barr Virus. Association with Peptic Ulcer Disease. Analytical Cellular Pathology. 2015;164840:7.

73. Rosenstock S, Jørgensen T, Bonnevie O, Andersen L. Risk factors for peptic ulcer disease: a population based prospective cohort study comprising 2416 Danish adults. Gut. 2003;10.

74. Lin HY, Weng SF, Lin HJ, Hsu CC, Wang JJ, Su $\mathrm{SB}$, et al. Peptic Ulcer Disease in Healthcare Workers: A Nationwide Population-Based Cohort Study. PLoS ONE. 2015;10: e0135456.

75. Levenstein S, Rosenstock S, Jacobsen R, Jorgensen T. Psychological Stress Increases Risk for Peptic Ulcer, Regardless of Helicobacter pylori Infection or Use of Nonsteroidal Anti-inflammatory Drugs. Clin Gastroenterol Hepatol. 2015;13:498-506.

Cite this article as: Asali AM, Alghamdi MA, Fallatah SA, Alholaily WA, Aldandan RG, Alnosair AH. Risk factors leading to peptic ulcer disease: systematic review in literature. Int J Community Med Public Health 2018;5:4617-24. 